\title{
ADMINISTRATIVE LAW AND RAILROAD RETIREMENT LEGISLATION*
}

\author{
STNEY B. JACOBY $†$
}

$\mathrm{I}$

N THE last decade important changes have taken place in the complexion of public law. In addition to fundamental modifications in the approach of courts to questions of constitutional law, an important development has been the constantly increasing significance of the field of administrative law. While until several years ago the emphasis had been on constitutional law, it has now shifted to problems of administrative law. Constitutional law, with the broadened interpretation of the interstate commerce clause and with the Supreme Court's greater restraint in invalidating statutes under the due process provisions, became somewhat stabilized. Administrative law, on the other hand, has become a muchdebated subject presenting novel questions. This increasing significance of administrative law is reflected in the greater number of Supreme Court decisions in the field, handed down within recent years, and is observable in every branch of governmental activity and regulation. It is apparent in the field of railroad retirement benefits with which the present article will be specifically concerned.

Establishment of a system of governmental retirement and disability benefits for employees in the railroad industry was the forerunner in this country of a general federal social security program. In the earlier stages questions of constitutionality were the principal legal issues presented by the railroad retirement legislation. The Supreme Court decision in Railroad Retirement Board v. Alton Railroad Co., ${ }^{\mathrm{x}}$ a five-to-four decision declaring unconstitutional the Railroad Retirement Act of June $27,1934{ }^{2}$ as against due process and as not falling within the scope of the interstate commerce clause, was one of the major defeats inflicted upon New Deal legislation by the Supreme Court in its role as reviewer of the constitutionality of federal legislation. Thereafter, constitutional law only rarely constituted an issue in the court decisions in the field of railroad retire-

\footnotetext{
* Although the writer is employed as an attorney by the Railroad Retirement Board, the views expressed herein are entirely those of the writer personally, and nothing herein contained is to be construed as the official opinion of the Railroad Retirement Board. The writer wishes to express his sincere gratitude to the members of the board's legal staff, especially to $\mathrm{Mr}$. Paul M. Johnson, Principal Attorney, for many valuable suggestions, but the responsibility for all statements made of course rests solely with the writer.

$\dagger$ Attorney, United States Railroad Retirement Board.

295 U.S. 330 (1935). $\quad 248$ Stat. I283.
} 
ment legislation. True, a decision of the district court for the District of Columbia ${ }^{3}$ held invalid the Carriers Taxing Act of $1935,{ }^{4}$ which had been enacted, together with the Railroad Retirement Act of $x 935,{ }^{5}$ in an attempt to overcome the effect of the invalidation of the legislation of 1934 , the Carriers Taxing Act providing for the collection of the tax and the Railroad Retirement Act providing for the payment of benefits; the Court, also, declared that the two acts constituted inseparable parts of one legislative scheme. This decision, however, was not carried further; instead, representatives of the railroads and representatives of railroad labor organizations together drafted a new bill. The compromise bill finally became the Railroad Retirement Act of $1937^{6}$ which, though not repealing, amended and largely superseded the r935 act.

Constitutional issues were not passed upon in any of the subsequent court opinions dealing with cases arising under the Railroad Retirement Acts. In a suit, under the Supreme Court's original jurisdiction, to enjoin the members of the Railroad Retirement Board from enforcing the provisions of the Railroad Retirement Acts of $x 935$ and 1937 (together with a suit to enjoin the enforcement of the Carriers Taxing Act of $1937^{7}$ with which the Retirement Acts were alleged to form a single legislative scheme), the State of California claimed the unconstitutionality of both the I935 and the I937 acts, if they were applied to the State Belt Railroad owned and operated by the State of California. However, the Supreme Court ${ }^{8}$ dismissed the bill for lack of equity, without considering the question of constitutionality.

The constitutionality of railroad retirement legislation was considered in only one court decision since 1936 , namely in the opinion of the Circuit Court of Appeals for the Ninth Circuit in California v. Anglim ${ }^{9}$ which was

3 Alton R. Co. v. Railroad Retirement Board, 16 F. Supp. 955 (1936).

${ }_{4}^{4}$ Stat. 974, 45 U.S.C. $\$ 24$ I-253; repealed by $\S$ II of the Carriers Taxing Act of 1937, 50 Stat. 440,45 U.S.C. $\$ 27 x$.

${ }^{5} 49$ Stat. 967,45 U.S.C. $\S 215^{-228 .} \quad{ }^{6} 50$ Stat. 307,45 U.S.C. $\$ 228 \mathrm{a}-228 \mathrm{~s}$.

' $5 \circ$ Stat. 435,45 U.S.C. $\S 26 \mathrm{I}-273$ (now ch. 9 , subch. B, of the Internal Revenue Code).

${ }^{8}$ California v. Latimer, 305 U.S. 255 (1938).

9 129 F. 2 d 455 (1942), cert. denied, 317 U.S. 669 (1942). That the case of Railroad Retirement ${ }^{\prime}$ Board v. Alton R. Co., supra, note $I$, is no longer considered controlling by the present Supreme Court is apparent from a statement by the Supreme Court in the case of Wickard v. Filburn, 3I7 U.S. III, at I22, note 2I (I942), in which Mr. Justice Jackson listed the Alton case, together with certain other cases (one of which has since been expressly overruled and another expressly limited), as instances in which the commerce clause was interpreted restrictively during a certain period in the Court's history; Mr. Justice Jackson then continued in his opinion as follows:

"Even while important opinions in this line of restrictive authority were being written, how- 
a case arising under the Carriers Taxing Act of 1937 . In that opinion, which is indicative of the changed approach of courts in dealing with the interstate commerce clause, the Circuit Court of Appeals, proclaiming that it was not overruling the Supreme Court decision in the Alton case and not violating stare decisis, invoked the principle of constitutional law that the facts determining the constitutionality of an act may vary from time to time, and stated:

Congress certainly could have a rational concept of the effect of a legislatively enforced railroad pension different in I937 from that in $x 934$.

Taking judicial notice of the fact that a pension not dependent upon employer largess has a stronger appeal to the loyalty of railroad employees than a pension dependent upon such largess, the circuit court de-

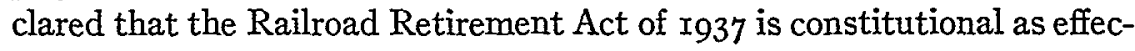
tually aiding interstate commerce.

While the practical significance of constitutional law problems thus has decreased in the field of railroad retirement legislation, weighty issues of administrative law have arisen. Controlling importance of the statutory material has always been characteristic of the field of administrative law, and because of the differences between individual statutory enactments administrative law has therefore largely defied generalizations. Attempts have, of course, been made to provide some uniformity. The ill-fated Walter-Logan Bill, the bill proposed as a fruit of the studies of the Attorney General's Committee on Administrative Procedure, ${ }^{\text {10 }}$ and the "Administrative Procedure Bill" adopted on February 28, I944 by the House of Delegates of the American Bar Association and introduced in Congress on June $2 \mathrm{I}, \mathrm{I} 944^{\mathrm{II}}$ are outstanding examples of suggestions for legislation designed to provide some uniformity. Evolution of general principles of administrative law has occasionally been attempted by the courts. The Railroad Retirement Act, to a degree exceeding most other federal statutes, has provided the courts with an opportunity to enunciate general principles with respect to basic questions of administrative law, for the reason that this act, unlike many other Federal statutes, lacks express language on certain fundamental issues of administrative law.

\footnotetext{
ever, other cases called forth broader interpretations of the Commerce Clause destined to supersede the earlier ones, and to bring about a return to the principles first enunciated by Chief Justice Marshall in Gibbons v. Ogden....." (Italics supplied.)

10 Final Report of the Attorney General's Committee on Administrative Procedure I92 (I94).

1x 78 th Cong., 2d Sess., S. 2030 and H.R. $508 x$.
} 


\section{JUDICIAL REVIEW OF ADMINISTRATIVE ADJUDICATIONS}

Traditional doctrine considers the problem of judicial review of administrative adjudications as the basic issue of administrative law, although actually with respect to the great majority of administrative adjudications the right of judicial review is of mere secondary importance. Establishment of fair and efficient procedures before administrative bodies, especially in the matter of evidence before the administrative agencies, possesses considerably greater practical significance. Both issues, the question as to the scope of judicial review as also the problem of evidence, have been determined in litigation arising under the Railroad Retirement Act.

The section of the Railroad Retirement Act of $1937^{\mathrm{I2}}$ dealing with court review reads as follows:

\section{COURT JURISDICTION}

Sec. II. An employee or other person aggrieved may apply to the district court of any district wherein the Board may have established an office or to the District Court of the United States for the District of Columbia to compel the Board (r) to set aside an action or decision of the Board claimed to be in violation of a legal right of the applicant or (2) to take action or to make a decision necessary for the enforcement of a legal right of the applicant. Such court shall have jurisdiction to entertain such application and to grant appropriate relief. The decision of the Board with respect to an annuity, pension, or death benefit shall not be subject to review by any court unless suit is commenced within one year after the decision shall have been entered upon the records of the Board and communicated to the person claiming the annuity, pension, or death benefit. The jurisdiction herein specifically conferred upon the Federal courts shall not be held exclusive of any jurisdiction otherwise possessed by such courts to entertain actions at law or suits in equity in aid of the enforcement of rights or obligations arising under the provisions of this Act or the Railroad Retirement Act of 1935 .

It appears noteworthy that the provision lacks express language on the scope of the court's jurisdiction with respect to determinations of questions of fact. ${ }^{13}$ Specific'provisions in that regard are found in many federal

\footnotetext{
I2 This section alone is now applicable to court reviews, whether a case arises under the I937 act or whether it is a case which, in accordance with the provisions of the I937 act $(\$ 202)$, is still to be adjudicated under the 1935 act. Section 9 of the 1935 act, which dealt with court jurisdiction, has been wholly superseded by section $\mathrm{I} r$ of the $\mathrm{x} 937$. act. With respect to the question here considered-the scope of judicial review-section 9 was no more informative than section II of the 1937 act; in fact, not even the words "review by any court," used in section II of the 1937 act, occurred in the r935 act.

The language of section II of the I937 act has been characterized as "rather unique." Final Report of Attorney General's Committee on Administrative Procedure 83 (r94I).

$x_{3}$ Ray A. Brown, Fact and Law in Judicial Review, 56 Harv. L. Rev. 899 (I943), discussing a number of Supreme Court cases on the scope of judicial review, attempts to show that the courts have had great difficulty in distinguishing between questions of fact and questions of law, and that recently this distinction has given way to a pragmatic test: which body-court or
} 
statutes and, in fact, have been included in recent legislation as a matter of general practice. ${ }^{x 4}$ For example, in the related field of general old-age and survivors benefits section $205(\mathrm{~g})$ of the Social Security Act, as amended, ${ }^{15}$ provides specifically that: "The findings of the Board as to any fact, if supported by substantial evidence, shall be conclusive." While the language of the statutes concerning finality of findings of fact varies considerably, this so-called "substantial evidence" rule ${ }^{\mathrm{x}}$ is frequently specified in federal legislation. It is contained, for instance, in the Fair Labor Standards Act, ${ }^{x 7}$ the Civil Aeronautics Act of $x 938,{ }^{x 8}$ the Securities Exchange

administrative agency-has the better expert qualification for deciding the issue presented. While it cannot be denied that, as in other fields of law, so too in the field of judicial review no clear distinction is feasible between questions of fact and questions of law, the test suggested would not seem to offer a more workable standard.

The present article will be concerned with the review of questions of fact. With respect to pure questions of law (questions of statutory interpretation) arising under the Railroad Retirement Act, the Court of Appeals for the District of Columbia stated that this "is a field in which courts are regarded as having some expertness just as administrative tribunals have special knowledge of the recurring factual patterns in their several spheres of activity," and that administrative decisions of questions of law with respect to matters as to which there was, in the opinion of the court, no long administrative interpretation may be set aside "although the Board's interpretation of the Act may not be plainly erroneous." Railroad Retirement Board v. Bates, I26 F. 2d 642 (I942).

John Dickinson, Judicial Review of Administrative Determinations, A Summary and Evaluation, 25 Minn. L. Rev. 588, 592 (I94I), suggests a more realistic and better solution of the problem. Citing Brown Lumber Co. v. Louisville \& Nashville Railroad Co., 299 U.S. 393 (1937), as suggesting such approach, he advocates a distinction between legal determinations of a specialized character and determinations of settled legal principles which are not technical in nature. With respect to the former-and the issues which were involved in the Bates case obviously fell within that category - the courts should not disturb the administrative finding "if there is room for reasonable doubt as to the correctness of the administrative determination," but should disturb the finding only if the error is "clear and palpable."

${ }^{{ }_{4}}$ The "Administrative Procedure Bill," supra, note $I I$, which is a proposal contemplating a uniform systern for all peace-time activities of the federal government, contains an elaborate provision ( $\$ 9$ (f) ) on the scope of judicial review. With respect to the review of determinations of fact, it is provided that administrative actions may be set aside if "unsupported by competent, material, and substantial evidence, upon the whole record as reviewed by the court, in any case in which the action, rule, or order is required by statute to be taken, made, or issued after administrative hearing." Limitation of the substantial evidence rule in that manner would appear undesirable with respect to the federal disbursing agencies (which require informal adjudication of large numbers of simall claims), in view of the formality required for such hearings by the proposed bill. Doubts might even be raised under that bill as to the applicability of the substantial evidence rule to the determinations under the Railroad Retirement Act; see infra, pp. 56 ff.

${ }^{{ }_{5}} 53$ Stat. ${ }_{3} 68$ (I939) 42 , Ủ.S.C. $\$ 405$ (g).

${ }^{16}$ For an illuminating discussion of the rule see Stason, "Substantial Evidence" in Administrative Law, 89 U. of Pa. L. Rev, I026 (I94I). See also Pennock, Administration and the Rule of Law, pp. I48 ff. (r94I); 2 Vom Baur, Federal Administrative Law, $\$ \$ 575$-595 (I942); Chamberlain-Dowling-Hays, The Judicial Function in Federal Administrative Agencies p. 32 ff. (1942).

${ }^{17} 5^{2}$ Stat. $1065(1938) 29$ U.S.C. $\$ 210$.

${ }^{18} 5^{2}$ Stat. 1024, 49 U.S.C. $\$ 646$ (e). 
Act of $1934,{ }^{I 9}$ the Public Utility Holding Company Act of $1935,{ }^{20}$ the Investment Company Act of $1940,{ }^{2 x}$ the Investment Advisers Act of $1940,{ }^{22}$ the Federal Power Act, ${ }^{23}$ the Federal Alcohol Administration Act, ${ }^{24}$ the Federal Food, Drug and Cosmetics Act, ${ }^{25}$ and the Federal Communications Act of $1934 .{ }^{26}$ Other statutes, such as the National Labor Relations Act, ${ }^{27}$ the Federal Trade Commission Act, ${ }^{28}$ the Railroad Unemployment Insurance Act, ${ }^{29}$ and the Securities Exchange Act of $1933,{ }^{30}$ make findings of fact by the administrative body conclusive "if supported by evidence"; sometimes, the only language found is that findings and orders shall be "prima facie evidence of the facts therein stated" (orders of the Interstate Commerce Commission with respect to suits for reparation awards). ${ }^{3 x}$

Under these circumstances the lack in the Railroad Retirement Act of express language on the scope of judicial review of questions of fact was bound to become an issue to be determined by the courts. To be sure, some earlier statutes likewise lack language specifying the scope of judicial review. The outstanding example is the Interstate Commerce Act which for many years was the most significant federal statute as regards the evolution of principles of administrative law. As originally enacted in $1887,{ }^{32}$ section I 6 of the act stipulated that a "report" of the commission should be "prima facie evidence of the matters therein stated." The original procedure of the act, under which orders of the commission did not become

${ }^{29} 48$ Stat 902 , 15 U.S.C. $\$ 78(y)$.

${ }^{20} 49$ Stat. 835,15 U.S.C. $\$ 79 x$ (a).

${ }^{23} 49$ Stat. 860 (1935) I6 U.S.C. $\$ 825$ l (b).

${ }^{2 \pi} 54$ Stat. 842 , I5 U.S.C. $\$ 80 a-42$ (a).

${ }^{24} 49$ Stat. 980 (I935) 27 U.S.C. $\$ 204$ (h).

${ }_{22} 54$ Stat. 856 , I5 U.S.C. $\$ 80 \mathrm{~b}-\mathrm{I}_{3}$ (a).

${ }_{25} 52$ Stat. 1053 (1938) 21 U.S.C. $\$ 355$ (h).

${ }^{26}$ With reference to orders of the Federal Communications Commission granting or denying construction permits, station licenses, and renewals or modifications thereof, or suspending a radio operator's license: 48 Stat. I094, 47 U.S.C. $\$ 402$ (e) ("findings of fact by the Commission, if supported by substantial evidence, shall be conclusive unless it shall clearly appear that the findings of the Commission are arbitrary or capricious.")

${ }^{27} 49$ Stat. 454 (I935) 29 U.S.C. $\$$ I60 (e).

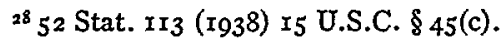

${ }^{29} 52$ Stat. I Ior (I938) 45 U.S.C. $\$ 355$ (f). A proposed bill, the "Railroad Social Insurance Act" (78th Cong., 2 d Sess., S. I9I I, H.R. 4805) which would amend the Railroad Retirement and the Railroad Unemployment Insurance Acts, likewise contains an express provision $(\$ 407(\mathrm{~g}))$.

${ }^{30} 48$ Stat $80, I_{5}$ U.S.C. $\$ 77$ (i).

${ }^{31} \S$ I6 (2) of the Interstate Commerce Act, 34 Stat. 590, as amended by Act, June I8, I9I0, ch. $309, \S \mathrm{r}_{3}, 36$ Stat. 554,49 U.S.C. $\$$ I6 (2); and $\$ 308$ (e) of the Interstate Commerce Act (concerning water carriers) added by Act of September I8, 1940, ch. 722, title II, $\$ 201,54$ Stat. 940, 49 U.S.C. 908 (e) (Supp. I942).

32,24 Stat. 379,385 ( 1887 ). 
operative without the intervention of a court, amounted substantially to a new trial in the courts. Nevertheless, it is interesting to note that even at that time judicial statements were made to the effect that it is not a function of the courts to weigh the evidence adduced; for example, whether because of dissimilar circumstances and conditions a carrier was justified, when engaged in the transportation of foreign freight, to charge more for a shorter than for a longer distance on its own line, was declared by the Supreme Court in an early opinion to be a question "of fact, peculiarly within the province of the Commission." ${ }^{33}$

In Igo6 the so-called Hepburn Amendment to the Interstate Commerce Act was adopted and the provision on judicial review was substantially modified. ${ }^{34}$ The prima facie evidence rule was retained only as to suits for reparation awards, but abolished as to all other cases. However, the importance of the Hepburn Amendment lies in its provision making the orders of the Interstate Commerce Commission (except those for money damages) operative without intervention of a court, the burden in the enforcement procedure being thereby shifted to the private parties affected. It was after the enactment of the Hepburn Act, i.e., in the absence of specific statutory language on the scope of judicial review, that the courts worked out the principles of judicial review in cases arising under the Interstate Commerce Act. ${ }^{35}$

One of the leading cases is Interstate Commerce Commission v. Union Pacific Railroad Co. ${ }^{36}$ involving a rate order of the commission. By section I5(I) of the act the commission is empowered to order the discontinuance of any rate, regulation, or practice of a carrier subject to the act, which it finds to be "unjust or unreasonable or unjustly discriminatory or unduly

33 Cincinnati, N.O. Tex. Pac. Railway v. Interstate Commerce Commission, x62 U.S. I84, r94 (1896).

34 Act of June 29,1906 , ch. 359I, $\$ 5,34$ Stat. 59x. In Igr3 section I9 (a), providing for a valuation of the several classes of carrier property, was added to the Interstate Commerce Act (Act of March I, I9I3, ch. 92, 37 Stat. 70r, 49 U.S.C. § I9 (a)). Subdivision (i) of section I9 (a) provides that all final valuations by the commission "shall be prima facie evidence of the value of the property in all proceedings under this chapter . . . . and in all judicial proceedings for the enforcement of this chapter, and in all judicial proceedings brought to enjoin, set aside, annul, or suspend, in whole or in part, any order of the Interstate Commerce Commission."

35 For an interesting comparison of the judicial treatment accorded the orders of the Interstate Commerce Commission and those of the Federal Trade Commission, see McFarland, Judicial Control of.the Federal Trade Commission and the Interstate Commerce Commission, I920-I930 (I933) (showing that a larger degree of administrative finality was granted by the courts to orders of the Interstate Commerce Commission-in the absence of specific statutory language - than to those of the Federal Trade Commission, whose governing act contains specific language, see supra, note 28 ).

${ }^{36} 222$ U.S. 54I, at 547 (I9I2); see also Interstate Commerce Commission v. Louisville and Nashville Railroad Co., 227 U.S. 88 (r913); Western Paper Makers' Chemical Co. v. United States, 27 I U.S. 268, 27 I (I926); Virginia Railway v. United States, 272 U.S. 658, 663 (I926.) 
preferential or prejudicial," and to prescribe rates, regulations, or practices that will be "just and reasonable." In the Union Pacific case Mr. Justice Lamar used the following language, which has become a classic pronouncement in the field of administrative law:

.... the orders of the Commission are final unless (I) beyond the power which it could constitutionally exercise; or (2) beyond its statutory power; or (3) based upon a mistake of law. But questions of fact may be involved in the determination of questions of law, so that an order, regular on its fact, may be set aside if it appears that (4) the rate is so low as to be confiscatory and in violation of the constitutional provision against taking property without due process of law; or (5) if the Commission acted so arbitrarily and unjustly as to fix rates contrary to evidence, or without evidence to support it; or (6) if the authority therein involved has been exercised in such an unreasonable manner as to cause it to be within the elementary rule that the substance, and not the shadow, determines the validity of the exercise of the power.....

In determining these mixed questions of law and fact, the court confines itself to the ultimate question as to whether the Commission acted within its power. It will not consider the expediency or wisdom of the order, or whether, on like testimony, it would have made a similar ruling. "The findings of the Commission are made by law prima 'facie true, and this court has ascribed to them the strength due to the judgments of a tribunal appointed by law and informed by experience." Ill. Cent. v. I.C.C., 206 U.S. 44I. Its conclusion, of course, is subject to review, but when supported by evidence is accepted as final; not that its decision, involving as it does so many and such vast public interests, can be supported by a mere scintilla of proof-but the courts will not examine the facts further than to determine whether there was substantial evidence to sustain the order.

These principles were applied by the Court to different types of rate orders; they were applied, for example, in upholding an order of the commission permitting lower rail rates on sugar, to meet water competition on the Mississippi and Ohio Rivers, ${ }^{37}$ in sustaining an order of the commission under the long and short haul clause (section 4 of the act), ${ }^{38}$ and in upholding an order of the commission under the Transportation Act of I $920^{39}$ establishing divisions of joint rates among a group of carriers. ${ }^{4^{\circ}}$ They were declared to be applicable also to other types of orders of the commission, such as orders concerning the distribution of coal cars, ${ }^{4 \mathrm{I}}$ or

37 Mississippi Valley Barge Line Co. v. United States, 292 U.S. 282, at 286 (I934); "The structure of a rate schedule calls in peculiar measure for the use of that enlightened judgment which the Commission by training and experience is qualified to form .... It is not the province of a court to absorb this function to itself."

${ }^{38}$ As amended by Act of June I8, r9ro, ch. 309, 36 Stat. 539, 547; Intermountain Rate Cases, 234 U.S. 476 (rgI4).

39 Ch. 9 I $\$ 4 \mathrm{I} 8,4$ I Stat. 456,486 , amending $\$$ I5 of the Interstate Commerce Act, 49 U.S.C. $\S I_{5}(6)$.

40 New England Divisions Case, 26I U.S. I84, 203, 204 (I923).

41 Interstate Commerce Commission v. Illinois Central Railroad Co., 215 U.S. 452, 470 (I9IO). 
orders that a certain reshipping privilege was an undue preference or advantage to a city. ${ }^{42}$

The practice of the courts in matters involving the Interstate Commerce Commission has been of considerable importance with regard to many other federal agencies. One of the reasons is that a number of federal statutes have borrowed their provisions on court review from the Ürgent Deficiencies Act of ${ }^{19}{ }^{1} 3,{ }^{43}$ which was originally enacted for orders of the Interstate Commerce Commission. The Urgent Deficiencies Act, transferring to the district courts the jurisdiction possessed by the Commerce Court 44 "to enjoin, set aside, annul, or suspend in whole or in part any order of the Interstate Commerce Commission," was incorporated by reference in several more recent statutes setting up other regulatory schemes. It is of special interest that certain recent Supreme Court decisions on administrative finality arose under statutes in which this provision had been incorporated, but in which no additional language had been inserted expressly limiting the scope of such judicial review.

Statutory provisions of such a character were involved in Tagg Bros. \& Moorehead v. United States, ${ }^{45}$ Swayne \& Hoyt, Ltd. v. United States, ${ }^{46}$ and Rochester Telephone Corp. v. United States ${ }^{47}$ (arising under the Packers and Stockyards Act of $1921,{ }^{48}$ the Shipping Act, ${ }^{49}$ and the Federal Communications Act of $1934,{ }^{50}$ respectively). In both the Tagg Bros. case and the Swayne case the orders attacked were rate orders; in the former case the Supreme Court stated: $:^{5}$

A proceeding under $\$ 3^{I 6}$ of the Packers and Stockyards Act is a judicial review, not a trial de novo. The validity of an order of the Secretary, like that of an order of the Interstate Commerce Commission, must be determined upon the record of the proceedings before him, - save as there may be an exception of issues presenting claims of constitutional right, a matter which need not be considered or decided now .... On all

${ }^{2}$ United States v. Louisville \& Nashville R.R., 235 U.S. $3 x_{4}$ (I9I4).

${ }^{43}$ Act of October 22, I913; 38 Stat. 208, 219; 28 U.S.C. $\$ 4 I$, subd. (28); see, generally, Miller, The Relation of Interstate Commerce Commission Practice to Other Administrative Proceedings, passim (1939).

${ }^{44}$ See Act of June I8, I9Io, ch. 309, 36 Stat. 539 .

45280 U.S. 420 (1930).

${ }^{46} 300$ U.S. 297 (1937).

$4^{8} 42$ Stat. 168,7 U.S.C. $\$ 217$.

${ }^{47} 307$ U.S. I25 (I939).

${ }^{49} 39$ Stat. 738,46 U.S.C. $\$ 83$.

${ }^{50} 48$ Stat. 1064, ro93, 47 U.S.C. $\$ 402$ (a). An express provision making findings of fact of the commission conclusive unless it appears clearly that they are arbitrary or capricious is contained in section 402 (e) of the act, but only with respect to certain specified orders, see supra, note 26 . The order which was involved in the Rochester case did not fall within that group.

sx 280 U.S. 420 , at $443-444$ (r930). 
other issues his findings must be accepted by the court as conclusive, if the evidence before him was legally sufficient to sustain them and there was no irregularity in the proceeding.

Comparing the Shipping Act with the Interstate Commerce Act, the Supreme Court stated in the Swayne case: $:^{52}$

Both have set up an administrative agency to whose informed judgment and discretion Congress has committed the determination of questions of fact, on the basis of which it is authorized to make administrative orders.

Such determinations will not be set aside by courts if there is evidence to support them .... Whether a discrimination in rates or services of a carrier is undue or unreasonable has always been regarded as peculiarly a question committed to the judgment of the administrative body, based upon an appreciation of all the facts and circumstances affecting the traffic.

In the Rochester Telephone Corp. case the Federal Communications Commission had ruled that that corporation was under the "control" of the New York Telephone Company and thus subject to the act and the commission's orders issued thereunder, requiring all telephone carriers subject to the act to file schedules of their charges and to supply certain other information. Reviewing the history of adjudications under the Interstate Commerce Act, Mr. Justice Frankfurter thus formulated the doctrine of administrative finality, as developed by the Court in its "recognition of the Commission's expertise": 53

Even when resort to courts can be had to review a Commission's order, the range of issues open to review is narrow. Only questions affecting constitutional power, statutory authority and the basic prerequisites of proof can be raised. If these legal tests are satisfied, the Commission's order becomes incontestable..... So long as there is warrant in the record for the judgment of the expert body it must stand .... Having found that the record permitted the Commission to draw the conclusion that it did, a court travels beyond its province to express concurrence therewith as an original question.

Administrative decisions of a type totally different from rate orders were likewise held to be protected by the principle of administrative finality, despite the lack of express statutory language to that effect. For example, grants of disability benefits were thus treated. In Silberschein v. United States, ${ }^{54}$ the Director of the Veterans' Bureau, who was empowered by the War Risk Insurance Acts5 to "decide all questions arising

${ }^{52} 300$ U.S. 297, at 303-304 (1937).

${ }^{53} 307$ U.S. 125, at 139 (I939).

54266 U.S. 221 (1924).

${ }^{35}$ Act of August 9, I92I, ch. 57. $\S 2,42$ Stat. I48. Subsequently, a specific provision was enacted ( $\$ 5$ of the World War Veterans' Act, I924, 43 Stat. 608 ) providing, with respect to the director's decisions, that "all decisions of question of fact affecting any claimant .... shall be conclusive except as otherwise provided herein." 
under this Act," had discontinued the plaintiff's compensation on the ground that his disability had ceased to be compensable. In the Court's opinion the following statement occurs: $5^{56}$

The statute which creates the asserted right, commits to the Director of the Bureau the duty and authority of administering its provisions and deciding all questions arising under it; and in the light of the prior decisions of this court, we must hold that his decision of such questions is final and conclusive and not subject to judicial review, at least unless the decision is wholly unsupported by the evidence, or is wholly dependent upon a question of law or is seen to be clearly arbitrary or capricious.

Orders under a federal workmen's compensation scheme (the Longshoremen's and Harbor Workers' Compensation Act of I927) $^{57}$ were granted the same protection by the principle of administrative finality, although the statutory language involved merely was that "if not in accordance with law, a compensation order may be suspended or set aside, in whole or in part, through injunction proceedings, mandatory or otherwise, brought by any party in interest." 58

The case of Shields v. Utah Idaho Central Railroad Co., ${ }^{59}$ involving a determination of the Interstate Commerce Commission occasioned by questions of labor relations, afforded the Supreme Court an opportunity to enunciate generally the principles which determine whether or not the scope of judicial review of factual questions is limited in a particular instance, notwithstanding failure of the specific statute to include express language on the problem. In the Shields case the Interstate Commerce Commission had determined for the purpose of, and as, provided by, the Railway Labor Act, that a line operated by electric power was not an "interurban" electric railway excepted from the provisions of the Railway Labor Act. ${ }^{60}$ Mr. Chief Justice Fughes, clearly stressing the para-

${ }^{56} 266$ U.S. 221, at 225 (1924).

${ }^{57} 44$ Stat. 1424,33 U.S.C. $\$ 90 r$.

$5^{8}$ South Chicago Coal \& Dock Co. v. Bassett. 309 U.S. $25 x$ (I940). The case does not contain an elaborate discussion of the problem here under consideration, the court merely stating (at pp. 257-258): "So far as the decision .... turns on questions of fact, the authority to determine such questions has been confided by Congress to the deputy commissioner. Fence the Court of Appeals correctly ruled that his finding, if there was evidence to support it, was conclusive." Voehl v. Indemnity Ins. Co., 288 U.S. I62, I66 (I933); Del Vecchio v. Bowers, 296 U.S. 280, 287 (1935). For lower court decisions on the same statute see Wheeling Corrugating Co. v. McManigal, 4I F. 2d 593 (r930) and Harris v. Hoage, 66 F. 2d 80 I (I933).

${ }^{59} 305$ U.S. I77 ( $193^{8}$ ).

${ }^{60}$ As amended by Act of June $2 x, 1934,48$ Stat, II $85 ; 45$ U.S.C. $\$$ I5x. The Railway Labor Act's exemption provision is with respect to any "interurban" electric railway, unless it is operating as a part of a general steam-railroad system of transportation. By that act the Interstate Commerce Commission is "authorized and directed upon request of the Mediation Board or upon complaint of any party interested to determine after hearing whether any line operated by electric power falls within the terms of this proviso." The Railroad Retirement Acts ( $\$$ I (a)) 
mount significance of the intent of Congress, thus discussed the problem:6x

What is the scope of the judicial review to which respondent is entitled? As Congress had constitutional authority to enact the requirements of the Railway Labor Act looking to the settlement of industrial disputes between carriers engaged in interstate commerce and their employees, and could include or except interurban carriers as it saw fit, no constitutional question is presented calling for the application of our decisions with respect to a trial de novo so far as the character of the respondent is concerned. With respect to that question, unlike the case presented in Uniled States v. Idaho, 298 U.S. ro5, where the Interstate Commerce Commission was denied the authority to determine the character of the trackage in question (Id., p. I07), the Commission in this instance was expressly directed to make the determination. As this authority was validly conferred upon the Commission, the question on judicial review would be simply whether the Commission had acted within its authority ....

.... The sole .... question would be whether the Commission in arriving at its determination departed from the applicable rules of law and whether its finding had a basis in substantial evidence or was arbitrary or capricious. .... That question must be determined upon the evidence produced before the Commission.

This principle of the limitation of judicial review, as deduced from the statutory scheme involved (not from any express language), is shown in its full significance by a comparison of the Shields case with two other cases, likewise concerning an "interurban electric railway" exemption, in which the judicial review was held not to be limited, namely Piedmont $\mathcal{E}$ Northern Railway Co. v. Interstate Commerce Commission ${ }^{62}$ and United States v. Chicago, North Shore \& Milwaukee Railroad Co. ${ }^{63}$ In these cases it was held that under the statutory scheme there involved the particular determinations had not been intrusted to the authority of the Interstate Commerce Commission. In both cases injunctions had been brought by the government-in the former case against construction of an extension without a certificate of public convenience and necessity from the commission (see section I, paragraphs I8-2I of the act), and in the latter case against the issuance of securities or the assumption of liability in respect of the securities of others without first having obtained authority from the commission (sections 20 (a) and I2, paragraph I). It was held that, con-

contain similar provisions, and the rule of the Shields case would clearly seem to be applicable to determinations of the Interstate Commerce Commission for railroad retirement purposes. Continental National Bank and Trust Company of Chicago v. Chicago North Shore and Milwaukee Railroad Company, D.C. N.D. Ill. East Div., in equity No. 16156 (November I8, I940), C.C.H., Railroad Unemployment Insurance Service, § 9r79. Cf. Sprague v. Woll, r22 F. $2 \mathrm{~d}$ I28, at $\mathrm{I}_{30}$ (I94I), cert. denied, $3 \mathrm{I}_{4}$ U.S. 669 (I94I).

6x 305 U.S. 177 , at $184,185(1938)$.

62286 U.S. 299 (I932).

${ }^{63} 288$ U.S. I (I933). 
trary to the Shields case, the determination of the "interurban electric railway" exemption had not been intrusted to the authority of the commission in such matters. ${ }^{64}$

It was against this background that the courts were faced with the problem of determining the scope of their jurisdiction in actions brought under section II of the Railroad Retirement Act of I937. As shown, section II is silent as to the scope of the courts' review of questions of fact, although there are some indications in the language of section II suggesting that the court jurisdiction provided for does not contemplate a trial de novo: such indications are the use of the word "review by any court," as also the fact that under section II the courts are to set aside board decisions "claimed to be in violation of a legal right of the applicant," or to take action "necessary for the enforcement of a legal right of the applicant."'65 (Italics supplied.)

In deciding the issue in question the courts were unable to obtain much assistance from the legislative history of section II of the I937 act and, in fact, none of the court opinions determining the scope of judicial review under that section was based on the legislative history of the provision. None of the Railroad Retirement acts (neither the act of 1934, nor the acts of I935 or I937) contains an express provision giving administrative finality to the factual determinations of the board; however, throughout

${ }^{64}$ Brown, op. cit., supra, note $\mathrm{I}_{3}$, in discussing this group of cases, attempts (at pp. 9I4, gr5) to explain them by the suggestion that the task of applying even words without previous legal connotations (such as the term "interurban electric railway") to the settled facts of a case is frequently considered a question of law. Contrary to clear statements by Mr. Chief Justice Hughes, Brown advances the following as an explanation of the Shields case: "Probably all the case stands for, however, is that once the court has given the definition of the term, the determination of whether the particular road meets that definition is one of fact." There seems to be no basis, in the opinions of the Court or in legal theory, for the suggestion that the character of a question could thus be modified by the mere fact that the Supreme Court had occasion to consider the term. The true reason for the difference between the Piedmont $\&$ Northern and North Shore cases on the one hand, and the Shields case on the other, seems to lie in the different character of the determinations; under the statutory scheme, as interpreted by the Supreme Court, the commission is clothed with authoritative power with regard to determinations of the kind involved in the Shields case, while no such power was intrusted to the commission with respect to determinations such as were in issue in the two other cases.

Cf. also Texas Electric Ry. Co. v. Eastus, 25 F. Supp. 825 , at 832 (r938), aff'd 308 U.S. 5 I2 (I939), rehearing denied 308 U.S. 637 ( 1939 ), which reasoned that the distinction between the Shields opinion on the one hand, and the Piedmont \& Northern and Chicago, North Shore cases on the other, lies in the fact that the Railway Labor Act was amended in 1934 so as to authorize the Interstate Commerce Commission, upon request of the Mediation Board, to determine "after hearing" whether an electric line falls within the exemption proviso, and that the two latter cases had been decided prior to that amendment. It should be noted, however, that neither the Piedmont \& Northern case nor the Chicago, North Shore case arose under the Railway Labor Act.

${ }_{6}$ See South Chicago Coal \& Dock Co. v. Bassett, cited supra, note 58 ; under the statute there involved an order can be suspended or set aside "if not in accordance with law." 
the history of the provisions for judicial proceedings there is a clear emphasis on "judicial review" in characterizing the nature of the proceedings. The title "Judicial Review" was given to the sections on judicial proceedings (article V) in some of the earliest bills which were concerned with railroad retirement legislation, S. 3892 and $H$. R. I0023, $72 \mathrm{~d}$ Congress, Ist Session, introduced in the year I932, and S. $I_{529}$ and H. R. 4596, 73d Congress, Ist Session, introduced in I933. The provisions in those bills authorized the courts to set aside board decisions or to take other action "when the applicant shall establish his right to a judicial review." (Italics supplied.) This language, suggesting that no trial de novo was contemplated, was carried into section Io of the 1934 act, and the same indication is evident from the language of section II of the I937 act.

True, in section II of the bills first introduced in 1937 (H. R. 6956 and S. $2395,75^{\text {th }}$ Cong., Ist Sess.) a provision appeared that "in any such suit, the findings of the Board as to facts, unless contrary to the weight of the evidence, shall be binding upon the court." But neither H.R. 6956 nor S. 2395 ever became law. The House committee did not report on H.R. $695^{6}$, but instead reported favorably on a substitute bill, H.R. 75'9, which did not include the provision in question. The Senate then adopted H.R. 75I9, which was passed by both Houses of Congress and became the I937 act. In view of the fact that, at the hearings before the House committee leading to the replacement of H. R. $695^{6}$ by H. R. 75I9, deletion of the provision here in question was never specifically suggested, and in view of the fact that there is nothing in the hearings or the committee reports or the proceedings on the floor of Congress giving any indication whatever as to why the provision was not included in the new bill, it is obviously impossible under the rules of statutory construction to draw any conclusion as to Congressional intent from the omission. Any attempt to draw a conclusion would be mere speculation, especially when it is realized that during the steps leading to the enactment of the I937 act the provision on court jurisdiction was never acted on specifically by either of the committees or Houses of Congress, but that there was simply a substitution for the original bill of an entire new bill in which the deletion of the provision in question represented one of many changes. Accordingly, it is impossible to determine why the provision in question was not included in the new bill and whether the deletion thereof was considered as narrowing, broadening, or leaving unchanged, the scope of judicial review. Consequently, it is not permissible to base any conclusion on the omission of the provision in question from the I937 act.

However, the statutory scheme of the Railroad Retirement acts dem- 
onstrates conclusively that the authority to make determinations regarding the social insurance benefits provided for in the acts was clearly committed to the Railroad Retirement Board so that, in accordance with the principles enunciated by the Supreme Court, findings of fact by the board are conclusive, if supported by substantial evidence-notwithstanding the absence of express language to that effect. Special fitness of the administrative agency for deciding the factual questions involved, its "expertise" - declared by the Supreme Court to be the basis and justification of the doctrine of administrative finality-is peculiarly manifest in the case of the Railroad Retirement Board, in that under section Io (a) of the I937 act special qualifications are required for membership upon the board.$^{66}$ According to that provision the Railroad Retirement Board shall be composed of three members: "One member shall be appointed from recommendations made by representatives of the employees and one member shall be appointed from recommendations made by representatives of carriers, in both cases as the President shall direct, so as to provide representation on the Board satisfactory to the largest number, respectively, of employees and carriers concerned." ${ }^{\prime} 7$

That the determinations regarding the benefits of the railroad retirement system were intrusted to the Railroad Retirement Board, acting in the capacity of an administrative tribunal, clearly follows, also, from a number of other provisions of the act: It follows from section Io (b) which, entitled "Duties" of the board, provides that the board "shall have and exercise all the duties and powers necessary to administer this Act and the Railroad Retirement Act of I935"; and that "decisions by the Board upon issues of law and fact relating to pensions, annuities, or death benefits shall not be subject to review by any other administrative or accounting officer, agent, or employee of the United States." It is especially clear from subsection 2 of section ro (b), which reads as follows:

If the Board finds that an applicant is entitled to an annuity under the provisions of this Act or the Railroad Retirement Act of $x 935$ then the Board shall make an award

${ }^{65}$ The same was true under the 1935 Act $(\$ 6(\mathrm{a}))$. A similar rule applies to the board's appeals council set up by the board as an intermediate appeliate board under the authority of section Io (b) (5). According to section 260.2 (a) of the board's Regulations (4 Fed. Reg. I502 (April 7, I939); 20 Code Fed. Reg. 260.2 (a)), four of the five members of the appeals council shall have backgrounds of experience in the railroad industry.

${ }^{67}$ See also section Io (b) (4) of the act according to which in the employment of board employees under the civil-service laws and rules the board "shall give preference over all others to individuals who have had experience in railroad service, if, in the judgment of the Board, they possess the qualifications necessary for the proper discharge of the duties of the positions to which they are to be appointed," and section I5 $_{5}$ (c) directing the board to select two actuaries, "one from recommendations made by representatives of employees and the other from recommendations made by representatives of carriers," for an actuarial advisory committee with respect to the Railroad Retirement Account. 
fixing the amount of the annuity and shall certify the payment thereof as hereinafter provided; otherwise the application shall be denied.

It should further be noted that it is provided in subsection 4 of section Io (b) that the board shall "establish and promulgate rules and regulations to provide for the adjustment of all controversial matters arising in the administration of such Acts, with power .... to require and compel the attendance of witnesses, administer oaths, take testimony, and make all necessary investigations in any matter involving annuities or other payments"; that the board is given power to require all employers and employees, and officers, boards, commissions, etc., of the United States, to furnish information necessary for the administration of the acts; and that upon suit by the board the United States district courts are given jurisdiction to compel obedience to any order of the board issued pursuant to this section.

The intent of Congress thus can clearly be gathered from the statutory scheme of the Railroad Retirement Act. It was to set up the Railroad Retirement Board as a genuine administrative tribunal possessing all powers usually enjoyed by such tribunals, and to entrust it with the authoritative determination of questions of fact arising in the administration of the acts. It was so held by the courts in a number of cases and, in fact, no decision of any court ever denied the applicability of the principle of administrative finality to the determination of factual questions confided to the board for administration.

The most extensive discussion of the problem is contained in two opinions written by Judge Underwood of the District Court for the Northern District of Georgia, Atlanta Division. In these two cases, (South v. Railroad Retirement Board ${ }^{68}$ and Holloway v. Railroad Retirement Board, ${ }^{69}$ identical language was used to show that the review contemplated by section II is a judicial review, not a trial de novo; i.e., that the scope of review of questions of fact is limited under that section to determining whether there was substantial evidence in the record before the board to support the attacked finding. Judge Underwood made the following statement in both opinions: $:^{70}$

${ }^{68} 43$ F. Supp. 9 II (1942).

${ }^{69} 44$ F. Supp. 59 (I942).

${ }^{70} 43$ F. Supp. 9rI, at $9 \mathrm{I}_{2}$ (1942); 44 F. Supp. 59, at 6x (I942); see also the opinion in the case of Dunlap v. Railroad Retirement Board, D.C. N.D. Ga., Civil No. 2459 (November 5, I943), C.C.H. Railroad Unemployment Insurance Service, § 9401, in which Judge Underwood stated: "This proceeding is a review of the Board's findings and not a proceeding de novo. The findings under review must stand, if supported by substantial evidence and not in violation of law. This was decided by this Court in the cases of Holloway v. Railroad Retirement Board .... and South v. Railroad Retirement Board." 
The determination of this question of fact was by the Act entrusted to the Board, and its decision, if supported by substantial evidence, will not be set aside by the Court. A review of the decision by a District Court is provided for in Section II of the Act, but the review contemplated by the Section is a judicial review, not a trial de novo. The word "review" is used in the Section where it is provided that: "The decision of the Board with respect to an annuity, pension, or death benefit shall not be subject to review by any court unless suit is commenced within one year after the decision," etc.

Where an administrative agency has been set up to whose informed judgment and discretion Congress has committed the determination of questions of fact, on the basis of which it is authorized to make administrative orders, "such determinations will not be set aside by courts if there is evidence to support them. Even though, upon a consideration of all the evidence, a court might reach a different conclusion, it is not authorized to substitute its own for the administrative judgment." Swayne \& Hoyt, Ltd., v. United States, 300 U.S. $297,303,57$ S. Ct. 478, 48I, 8I L. Ed. 659 . "So long as there is warrant in the record for the judgment of the expert body it must stand," and where the Court has "found that the record permitted the Commission to draw the conclusion that it did, a court travels beyond its province to express concurrence therewith as an original question." Rochester Tel. Corp. v. United States, 307 U.S. $125, x_{45}, x_{4} 6,59 \mathrm{~S}$. Ct. $754,764,83$ L. Ed. Ir47.

To hold otherwise would make the Board "but a mere instrument for the purpose of taking testimony to be submitted to the courts for their ultimate action." (United States v. Louisville \& N. Railroad Co. 235 U.S. 3I4, 35 S. Ct. II3, II4, 59 L. Ed. 245); and if it be held that the Act requires a trial de novo and not a "review" of the Board's decision, the hearing before the Board will accomplish little but delay.

The rule above stated is the rule uniformly applied to the findings of administrative officials and boards charged with the duty of finding facts and subjected to review by the courts when their orders are "not in accordance with law." Wheeling Corrugating Co. v. McManigal, 4 Cir. 4r F. 2d 593, 594.

Such has been the rule announced in construing the following statutes and powers of administrative officers [citing authorities].

Of the two cases only the South case was appealed and in the opinion of the Circuit Court of Appeals for the Fifth Circuit ${ }^{7 x}$ the problem here under consideration was treated as follows:

We think it too clear for argument that the statute in terms provides not for a trial de novo but for a review of the Board's proceedings and for an affirmance of the order and decision unless it is made to appear that the order is without legal support, that is, that it is either without evidence to support it, or is based on an incorrect theory of law. It is elementary law, as well in cases where statutory review is not provided for as if cases where it is, tnat the findings and decisions of administrative agencies, when within the scope of the authority conferred upon them, may not be set aside or otherwise interfered with by the courts where they are supported by substantial evidence. But it is especially true in the case of a statutory review on the record such as is provided here; that the jurisdiction and function of the court is supervisory and not original; that it is to review the findings and order for error and not to retry the matter; and

${ }^{7 I}$ I3I F. 2d 748, at 750 (I942), cert. denied, 3I7 U.S. 70I (I943). 
that the order under review must stand, if supported by substantial evidence, and not in violation of law.

The Circuit Court of Appeals for the Second Circuit likewise held that the principle of administrative finality is applicable to the board's determinations of questions of fact. Citing the above-mentioned cases as precedents, the court stated in Ellers v. Railroad Retirement Board:72

In an action to review a decision of the Board, the merits of the plaintiff's claim are not to be tried de novo. The only issue open as to the facts is whether the Board's findings are supported by substantial evidence [citing cases] .... Even when a court upon a consideration of all the evidence might reach a different conclusion, it may not substitute its own for the administrative judgment.

Finally, reference may be made to two additional district court opinions in which the same principle was expressed: Bruno v. Railroad Retirement Board,,$^{73}$ and Taylor v. Latimer, Railroad Retirement Board ${ }^{74}$ and to a number of unreported decisions by district courts also applying the doctrine of administrative finality to determinations by the board. ${ }^{75}$

This application of the principle of administrative finality to determinations under the Railroad Retirement Act, in the absence of express statutory language, is a recognition of the clear trend of American administrative law. In the development of judicial review administrative finality of factual determinations by administrative agencies ${ }^{76}$ has become

$7^{2}$ I32 F. 2d 636, at 639, 640 (I943).

${ }^{73} 47$ F. Supp. 3 (I942).

${ }^{74} 47$ F. Supp. 236, at 238 (I942): "It is the law which needs not be supported by the citation of authorities that, on reviewing the order or decision of an administrative board, a court or judge can go no further than to ascertain if the decision is supported by substantial testimony, and, if so, such decision cannot be overruled and must be confirmed."

75 Carey v. Murray Latimer, M.R. Reed and L. M. Eddy, Railroad Retirement Board, W.D. N.Y., Civil No. Irog (June 2, 1943); Wing v. Railroad Retirement Board, D. Colo. Civil No. 438 (December 2r, I942); Frawley v. Latimer, D. N.J., Civil No. 3 I99 (June 6, I944), and the following decisions by the district court for the District of Columbia: Bray v. Railroad Retirement Board, Civil No.82I (January 5, I943); Morris v. Railroad Retirement Board, Civil No. 10629 (May 28, I942); and Van Natta v. Railroad Retirement Board, Civil No. 4387 (January 9, I940).

The following unreported decisions in which the actions were voluntarily dismissed by the plaintiffs, are to the same effect: Donahue v. United States of America, Railroad Retirement Board, Morris W. Latimer, M. R. Reed, and I. M. Eddy, S.D. Iowa, Cent. Div., Civil No. IOg (February 2I, I94I); and by the District Court for the District of Columbia: Canfield v. Railroad Retirement Board, Civil No. I4264 (May 4, I942), and Bray v. Railroad Retirement , Board, Civil No. 82 I (January 28, r94I).

${ }^{76} \mathrm{~A}$ comprehensive exposition of the doctrine of judicial review in its different aspects was furnished by Mr. Justice Brandeis in his concurring opinion in the case of St. Joseph Stock Yards Co.v. United States, 298 U.S. 38, 73-93 (I936); for a general discussion of the relationship between courts and administrative agencies, see also Mr. Justice Frankfurter's opinion in the case of Federal Communications Commission v. Pottsville Broadcasting Co., 309 U.S. I34 (I940) (stressing that the technical rules derived from the interrelationship of judicial tribunals 
the general method in which the practical requirement of expertness in administering legislation has been reconciled with the tenet of AngloAmerican law which rejects the continental European practice of special administrative law courts, ${ }^{77}$ entirely separate from, and not integrated with, the machinery of the ordinary courts. While the above-mentioned decisions under the Railroad Retirement Act are not the first cases in which the principle of administrative finality was held to govern even in the absence of specific statutory language, they are nevertheless of special interest in any general appraisal of the evolution of administrative law. They indicate the extent to which the principle of administrative finality applies to different kinds of administrative action and in different forms of court review. The earlier cases, discussed on the preceding pages, involved other forms of administrative activity, and arose under other procedures. Most of them were concerned with regulatory bodies, primarily with rate and other orders of the Interstate Commerce Commission and certain other agencies. And, while of a somewhat different regulatory nature, the determination which gave rise to the Shields opinion likewise was a determination by the Interstate Commerce Commission. The decisions which arose under the Longshoremen's and Harbor Workers' Compensation Act concerned a totally dissimilar administrative function, namely a governmental regulation of "private rights." Different from the railroad retirement cases, they did not involve any "disbursing" activity on the part of the government. Only the Silberschein case, which arose under the War Risk Insurance Act, was a case falling within the same category of governmental activity as the railroad retirement legislation. However, different from the cases under the Railroad Retirement Act, the Silberschein case arose under the procedure of the Tucker Act (section 24 (20) of the Judicial Code) $; 7^{78}$ the procedural machinery of the other cases was a so-called "statutory bill in equity."79 The procedure established by section II of the Railroad Retirement Act, on the other hand, by authorizing the courts not only to set aside board decisions but also to take action or to make de-

forming a hierarchical system should not be mechanically applied to the judicial review over administrative agencies). Of course, textbook discussions of the problems involved are legion; see, e.g., two publications written from opposite points of view: Frank, If Men Were Angels

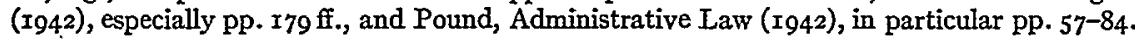

7 Such as the hierarchy of tribunals culminating in the conseil d'etat in France and the hierarchy of "Verwaltungsgerichte" in Germany.

${ }^{78} 28$ U.S.C. $\$ 4$ I (20).

79 The procedure for reviewing orders under the Urgent Deficiencies Act and the similar procedure under the Longshoremen's and Harbor Workers' Compensation Act; see Chamberlain-Dowling-Hays, The Judicial Function in Federal Administrative Agencies I66 ff. (I942). 
cisions necessary for the enforcement of legal rights, grants powers to reviewing courts somewhat in excess of the powers ordinarily conferred by statutory bills in equity. It partakes, at least to some extent, of the nature of a so-called "statutory appeal."80

The application of the principle of administrative finality to the railroad retirement cases thus clearly demonstrates that in the field of federal ${ }^{85}$ administrative law this doctrine has obtained recognition as a rule of general applicability, even in the absence of specific statutory language, and has become a rule applicable to different governmental functions and in various procedural schemes.

Section 9 ( $f$ ) of the recent "Administrative Procedure Bill" proposed by the American Bar Association provides with respect to the review of determinations of fact that the court shall set aside administrative determinations if it finds them:

(5) unsupported by competent, material, and substantial evidence, upon the whole record as reviewed by the court, in any case in which the action, rule, or order is required by statute to be taken, made, or issued after administrative hearing, or (6) unwarranted by the facts to the extent that the facts in any case are subject to trial $d e$ novo by the reviewing court.

Section 6 of the bill specifies that no administrative procedure shall satisfy the requirement of a full hearing unless certain formal conditions are complied with, such as the condition that a hearing be held by the ultimate authority of the agency, by hearing officers designated by the agency from members of the highest authority in the agency, or by fulltime examiners, and the condition that rules of evidence be observed; and section $\eta$ of the bill demands a certain formality in the decisions, namely preparation of initial decisions or intermediate reports, preparation of statements of reasons, findings of fact, and conclusions of law, etc. Sections 6 and 7 , as well as certain other provisions of the bill-if intended to apply to the Railroad Retirement Board ${ }^{82}$ - would seem inappropriate for administer-

80 Typical examples of which, fully developed, are the court review sections of the Public Utility Holding Company Act of $\mathbf{x} 935$, supra, note 20 , and of the Social Security Act, supra, note 15 .

${ }^{8 x}$ With respect to the similar rule of New York administrative law, see Benjamin, Administrative Adjudication in the State of New York $328 \mathrm{ff}$. (1942).

${ }^{82}$ Although the proposed bill does not appear to be unambiguous, it is possible that the provisions of the bill on "adjudication," "hearings," etc., were never intended to apply to the determinations of the board. See pamphlet entitled " $\mathrm{Legislative} \mathrm{Proposal} \mathrm{on} \mathrm{Federal} \mathrm{Adminis-}$ trative Procedure," published by the American Bar Association's Special Committee on Administrative Law in I944, at p. 28: "Of the two introductory exceptions to section 4, that limiting the application of the sections to those cases in which statutes require a hearing is the more significant, because thereby are excluded the great mass of administrative routine as well as pensions, claims, and a variety of similar matters in which Congress has intentionally or traditionally refrained from requiring an administrative hearing." 
ing the railroad retirement legislation under which numerous small claims must be promptly determined by the board. The existing procedure before the board is non-adversary in character in that there are no "parties" before the board and in that the board does not assume the role of an opponent of the claimant; the "hearing" procedure of the proposed bill, on the other hand, clearly contemplates adversary proceedings, controversial in character. Informal adjudication would be permitted under the bill only if a "controversy" is determined "by consent" (section 4 (b)), a rule which would limit the existing practice of informal administration to a restricted number of cases.

In addition, it might even be questioned whether the substantial evidence rule would continue to govern the scope of judicial review under the Railroad Retirement Act. A doubt might be raised by the above-quoted language of section 9 (f) of the proposed bill, according to which the substantial evidence rule shall apply in cases "in which the action .... is required by statute to be taken .... after administrative hearing." For there is no express statutory language in the Railroad Retirement Act which requires an administrative hearing before action is taken, although an elaborate hearing machinery is provided for in the board's regulations. ${ }^{83}$ That, nevertheless, no change was intended by the proposed bill would seem apparent from the following comment on subsection (f) of section 9, made by the proponents of the Bill, the American Bar Association's Special Committee on Administrative Law, in their recent pamphlet published in connection with the bill: 84 "The subsection does not attempt to expand the scope of judicial review ...." and "It should be noted that the sixth category, in accordance with the established rule, would permit trial de novo to establish the relevant facts .... as to the propriety of adjudications where there is no statutory administrative hearing...." The court decisions under the Railroad Retirement Act discussed above (as also some of the other cases mentioned) demonstrate that under existing law no express statutory language requiring administrative hearings is necessary for applying the substantial evidence rule. Apparently, implied general requirements of a "hearing" in the broadest sense of the term (such as the general requirement, included in the prohibition of "arbitrary" action, that some opportunity be given by the board to a claimant to present his case) were considered sufficient by the proponents of the bill to bring an administrative determination within the

\footnotetext{
${ }^{83}$ Sections 250.7-250.16 of the Regulations; 4 Fed. Reg. I499 (April 7, r939), 20 Code Fed.
} Reg. $250.7-250.16$.

${ }_{4} \mathrm{O}$. cit. supra, note 82 , at pp. 39,40 . 
"established rule" of existing law limiting judicial review to the substantial evidence test.

An attempt to apply the "Administrative Procedure Bill" to the activities of the other "disbursing" agencies of the federal government apparently would show the following: No difficulties, it seems, would be brought about with respect to the judicial review of determinations by the Veterans' Administration; in the case of pensions, compensation allowances, and special privileges judicial review is expressly precluded by statute, ${ }^{85}$ and the "Administrative Procedure Bill" (section 9 (h)) would leave that situation unchanged; trial de novo is apparently now granted in the case of war risk and national service life insurance claims, ${ }^{86}$ and it seems that no change would be made in that respect by the "Administrative Procedure Bill." Uncertainty might be caused in the case of the United States Employees' Compensation Commission. The statute ${ }^{87}$ governing the activities of that agency (which provides for workmen's compensation to federal employees) does not mention judicial review but, at the same time, does not contain a provision "expressly precluding judicial review," such as is contemplated by section $9(\mathrm{~h})$ of the "Administrative Procedure Bill." And since the statute may be construed as not requiring an administrative hearing, a suggestion might even be made, if the declaratory judgment procedure as described in section 9 (b) of the bill should be held applicable, that under the bill there should be a trial de novo with respect to the facts in the case of that agency. The suggestion does not appear sound to the writer, in addition to other reasons on the ground that apparently no consent to suit against the United States, not even for a declaratory judgment, is contained in the bill.

Finally, application of the bill to the Social Security Board would encounter the same objections concerning formality of procedure as were raised in the case of the Railroad Retirement Board. No question, apparently, could be raised as to the continued application of the substantial evidence rule contained in section 205 (g) of the Social Security Act, in view of the statutory requirement of a hearing in the act, section 205 (g) granting a right of court review to "any individual, after any final decision of the Board made after a hearing to which he was a party ....." (Italics supplied.)

${ }_{85}$ Act of March 20, I933, ch. 3, title I, $\S 5,48$ Stat. 9, 38 U.S.C. 705.

${ }^{86}$ See Act of June 7, I924, ch. $320, \S 19,43$ Stat. 612, 38 U.S.C. 445 , as amended. Cf. Hines v. United States ex rel. Marsh, I05 F. 2d 85 (I939); Kontovich v. United States, 99 F. 2d 66r (I938), cert. denied, 306 U.S. 65I (1939); and Act of October 8, r940, ch. 757, title VI, part I, $\$ 617,54$ Stat. 1014, 38 U.S.C. 8I7.

${ }^{87}$ Act of September 7, 1916, ch. $458, \S 36,39$ Stat. 749,5 U.S.C. 786. 


\section{"JURISDICTIONAL" QUESTIONS}

Only one court opinion under the Railroad Retirement Act qualified the applicability of the principle of administrative finality to the board's decisions of questions of fact. In Utah Copper Co. v. Railroad Retirement Board, Nevada Consol. Copper Corp. v. Railroad Retirement Board, ${ }^{88}$ the Circuit Court of Appeals for the Tenth Circuit made an exception with respect to so-called "questions of jurisdiction." The case involved the issue whether certain individuals were "employees" within the meaning of the Railroad Retirement Act. The court granted that as to all matters confided to the board for administration:

.... its judgments are final and conclusive if supported by substantial evidence and if free from arbitrary or capricious conduct. To hold otherwise would, in effect, be making of the Board a mere master to take the testimony and make recommendations of proposed findings of fact and conclusions of law.

However, it specifically excluded from that rule determinations of the question whether certain individuals were covered "employees" within the meaning of the act, ${ }^{89}$ on the ground that that question is "one of jurisdiction." Contending that the act is "silent on the power of the Board to pass upon the question of jurisdiction," the court concluded that:

.... in the absence of a specific provision in the act, expressly lodging the decision of the jurisdictional question in the Board, its decision, even if supported by competent evidence, is not final and may be independently examined by a court of review.

By making a reference to the concept "jurisdictional question," the court wandered into nebulous territory. The term "jurisdictionalquestion" is customarily used in discussions of administrative law in connection with the doctrine of the celebrated case of Crowell v. Benson. ${ }^{90}$ The doc-

${ }^{88}$ I29 F. 2d 358, at 36r (I942), cert. denied, 3I7 U.S. 687 (I942).

${ }^{89}$ The opinion indicates clearly that in the view of the court the issue as to whether a company is an "employer" within the meaning of the act is also considered a "question of jurisdiction," and thus under the theory of the court may likewise be examined independently by the reviewing court. Section I (b) of the 1937 act, in defining the term "employee" for the purposes of the act; uses the term "employer," which term is also specifically defined for the purposes of the act ( $\$$ I (a) of the act).

${ }_{90} 285$ U.S. 22 (1932). The case is one of the most widely discussed opinions in the field of administrative law. For analyses see, e.g., Black, The "Jurisdictional Fact" Theory and Administrative Finality, (1937) 22 Corn. L.Q. 349, 515; Dickinson, Crowell v. Benson: Judicial Review of Administrative Determination of Questions of "Constitutional Fact," 80 U. of Pa. L. Rev. 1055 (1932), 4 Selected Essays on Constitutional Law 993 (1938); Landis, The Administrative Process I3I-36 (I938); Hart, Judicial Review of Administrative Action: A Thesis, (I94) 9 Geo. W. L. Rev. 499, 509; Green, The Scope of Judicial Review of Administrative Action, I2 Rocky Mt. L.Rev. I73, I80 (I940). A comprehensive discussion is furnished by Chamberlain-Dowling-Hays, The Judicial Function in Federal Administrative Agencies 205207 (I942). For a pungent statement concerning the complexities raised by the doctrine of 
trine of that case, however, is clearly inapplicable to determinations under the Railroad Retirement Act. The doctrine of Crowell v. Benson, as the Supreme Court there stated,"9x applies only to cases involving "private rights" (as are involved in the workmen's compensation scheme of the Longshoremen's and Harbor Workers' Compensation Act under which that case arose) and then only to "constitutional jurisdictional facts"; i.e., a trial de novo of findings of an administrative agency is demanded by the Crowell v. Benson doctrine merely with respect to administrative determinations of facts upon which constitutional rights depend..$^{22}$ Of course, no such "private rights" can be involved in the system of governmental social insurance benefits which is provided for by the railroad retirement legislation. That legislation can give rise only to the other kind of cases, specifically excluded by the Supreme Court from the application of the Crowell v. Benson doctrine, namely to cases "which arise between the Government and persons subject to its authority in connection with the performance of the constitutional functions of the executive or legislative departments." Moreover, no issues of "constitutional jurisdictional fact" are presented by the application of the Railroad Retirement Act. ${ }^{93}$ In fact, the court in the Utah Copper Co. case did not cite the Crowell v. Benson decision and no attempt was made in the Utah opinion to predicate the conclusion on any principle of constitutional law. Divested of the sacrosanct implications of constitutional law with which, due to the Crowell v. Benson doctrine, problems of "jurisdiction" are ordinarily as-

"jurisdictional questions" in the subject of administrative law, see Mr. Justice Frankfurter, dissenting in City of Yonkers v. United States, 320 U.S. 685, at 695 (I944): "The opinions in Crowell v. Benson, 285 U.S. 22, and the casuistries to which they have given rise bear unedifying testimony of the morass into which one is led in working out problems of judicial review over administrative decisions by loose talk about jurisdiction."

9x 285 U.S. at pp. 5o, 57; cf. also Myers v. Bethlehem Shipbuilding Corp., 303 U.S. 4I, 49, 50 (I938); see comment in 26 Cal. L. R. 683 (r938), and Dickinson, Judicial Review of Administrative Determinations, A Summary and Evaluation, 25 Minn. L. Rev. 588, 597 (I94I) (correctly limiting the case to a situation in which the administrative power is used for the purpose of determining rights and liabilities between private individuals); and Blachly-Oatman, Federal Regulatory Action and Control I24 ff. (I940)

92285 U.S. at p. 56 : "It is the question whether the Congress may substitute for constitutional courts, in which the judicial power of the United States is vested, an administrative agency-in this instance a single deputy commissioner-for the final determination of the existence of the facts upon which the enforcement of the constitutional rights of the citizen depend." See Shields v. Utah Idaho Central Railroad Co., supra, note 59, footnote I3; Perkins v. Endicott Johnson Corp., I28 F. 2d 208, at 224 (I942), aff'd sub nom. Endicott Johnson Corp. v. Perkins, 3 I7 U.S. 5 OI (r943).

93 See supra, p. 28. Cf. also Helvering v. Davis, 30I U.S. 6rg (I937) (upholding the constitutionality of the old-age benefits provisions of the Social Security Act under the generalwelfare clause of the Constitution). 
sociated in writings on administrative law, the issue of "jurisdictional questions," as propounded in the Utah Copper case, thus assumes an undistinguished character and becomes a pure matter of statutory interpretation.

It is clear that, as a matter of policy, there is no justification for applying any doctrine of "jurisdictional facts" to the determinations under the Railroad Retirement Act. As stated by Dickinson, ${ }^{94}$ re-examination of "jurisdictional facts" grew up in connection with the review of summary official acts taken as a result of decisions not based on a formal hearing preserved in a record.

Where an administrative decision of fact is of a kind reached by an official simply as a result of a rough-and-ready personal inspection preliminary to summary action, it does not stand on all fours, so far as concerns the weight to which it is entitled, with a decision made as a result of a formal administrative hearing protected by procedural safeguards. A decision of fact made by a dairy or meat inspector as a preliminary to summary destruction of food is clearly not on the same footing with a decision of the Interstate Commerce Commission.

Obviously, determinations under the Railroad Retirement Act are not fact-findings "reached as result of a rough-and-ready personal inspection preliminary to summary action"; on the contrary, an elaborate hearing machinery was set up by the board in implementing the Congressional direction of section Io (b) of the Railroad Retirement Act of 1937 to "establish and promulgate rules and regulations to provide for the adjustment of all controversial matters arising in the administration of such Acts" (the Railroad Retirement Acts of 1935 and 1937 )..$^{95}$

In the Utah Copper case the Circuit Court relied for its conclusion on the decision of United States v. Idaho ${ }^{96}$ in which case the Supreme Court had held that the determination of the Interstate Commerce Commission there involved was "left by Congress to the decision of a court-not to the final determination of either the federal or a state commission." But the determination which had formed the basis for the Idaho decision was fundamentally different from the coverage determinations under the Railroad Retirement Act. The case was a so-called abandonment case under the Interstate Commerce Act. By that act, the Interstate Commerce Commission is given authority to determine whether convenience and necessity permit the abandonment of a line of railroad, "spurs" being

9480 U. of Pa. L. Rev. ro6o ff. (I932), 4 Selected Essays on Constitutional Law $998 \mathrm{ff}$. (1938).

95 See $\$ \S 250.7^{-250.16}$ of the board's Regulations; 4 Fed. Reg. I499'(April 7, r939), 20 Code Fed. Reg. 250.7-250.16.

298 U.S. I05 (1936). 
specifically excepted from such authority (section I (22)). Under the statute any party in interest can bring suit to enjoin an unauthorized abandonment, but an interested party other than a carrier cannot initiate before the commission any proceeding to determine whether or not a certain trackage is a "spur"; the only method by which such other interested party can secure a determination is by application to the court. Thus, under the statutory scheme of the Idaho case, independent judicial determinations of the jurisdictional question clearly were contemplated, regardless of whether the Interstate Commerce Commission had made a determination and whether it was a party to the judicial proceedings; hence, the determination of the jurisdictional question could not possibly have been committed to the commission. It was committed to the court.

Of course, it needs no elaboration to demonstrate that nothing similar to such a situation can arise in the administration of the Railroad Retirement Act. The Railroad Retirement Board is one of the disbursing agencies of the federal government. It is not a "regulatory body" such as, for example, the National Labor Relations Board, the Interstate Commerce Commission, or the Federal Communications Commission. The Railroad Retirement Act was not enacted for the purpose of establishing rules regulating the conduct of individuals. Consequently, under the Railroad Retirement Act there can be no "interested party" (as in the Idaho situation) which is both precluded from initiating proceedings before the agency and also limited by the statute in its freedom of action, in that its exercise of some pre-existing interest or right is made dependent upon an action of the board, as it was in the Idaho case. And there is also no special machinery, either under the Railroad Retirement Act or under the Judicial Code generally, providing for independent judicial proceedings to determine coverage questions under the Railroad Retirement Act, ${ }^{97}$ as there is in abandonment cases under the Interstate Commerce Act. In the Idaho case the suit had not been directed to setting aside any order of the commission; it was neither a so-called "statutory bill in equity" (such as the procedure of the Urgent Deficiencies Act, under which many of the Interstate Commerce Commission cases arise) nor a "statutory appeal," but was a suit brought under a provision of the Interstate Commerce Act (section $x(20)$ ) under which an independent right is granted to apply to the courts, disconnected from and not co-ordinated with the administrative procedure before the commission. Furthermore, even on more general grounds the Idaho opinion would seem to be of doubtful validity as a precedent for determinations by the Railroad Retirement Board. Though

${ }_{97}$ Cf. Endicott Johnson Corp. v. Perkins, 3I7 U.S. 501 (I943). 
the case is still good law, ${ }^{8}$ its doctrine clearly is very exceptional and not in accord with the general development of the law concerning administrative agencies; the Interstate Commerce Act, it should be noted, is the oldest federal statute setting up an administrative agency; and peculiar doctrines developed under its statutory scheme should not be extended to a modern statute such as the Railroad Retirement Act, which was enacted after the field of administrative law had witnessed a truly remarkable evolution, especially when it is realized that the doctrine of the Idaho case apparently was not extended, in any of the cases since reported, to any agency other than the Interstate Commerce Commission.

The Idaho case, it is suggested, fails to lend any support to the result reached by the Circuit Court of Appeals for the Tenth Circuit in Utah Copper Co. v. Railroad Retirement Board.

It likewise appears that a reference made in the Utah Copper opinion to a statement by Mr. Chief Justice Hughes in the above-cited case ${ }^{99}$ of Shields v. Utah Idaho Central Railroad Co. affords no support to the Court's conclusion. Stating that "in the absence of a specific provision in the act expressly lodging the decision of the jurisdictional question in the Board" the principle of administrative finality does not govern jurisdictional determinations, the court in the Utah Copper case cited as support a statement by Mr. Chief Justice Hughes in the Shields case that "the Commission in this instance was expressly directed to make the determination" of the jurisdictional question. But by that language the Chief Justice was merely describing the statutory provision of the Railway Labor Act which was involved in that case. He did not intend to lay down any rule that such express provision was a minimum requirement for the application of the doctrine of administrative finality to jurisdictional determinations. That such could not have been the intention of the Chief Justice is apparent from the fact that the Shields case was cited in subsequent opinions as authority for holding administrative determinations of jurisdictional issues conclusive, although the pertinent statutes did not contain express

\footnotetext{
${ }^{98}$ City of Yonkers v. United States, 320 U.S. 685, 689 (1944). In that case it was held, however, that when an application is made to a court to enjoin an unauthorized abandonment and the aid of the commission has previously been invoked, the courts, because of the special competence of the commission with respect to the matters involved, should not make jurisdictional determinations "without the basic jurisdictional findings first having been made by the Commission" (at.p. 689). This requirement indicates recognition by the Court of the special expertness of administrative agencies even in instances in which the principle of administrative finality is inapplicable, and might serve as a precursor signalizing the breakdown of the doctrine of the Idaho case.
}

${ }_{99} 305$ U.S. I77 (1938). 
provision granting power to make such determinations. ${ }^{\text {I00 }}$ In fact, application of the doctrine of administrative finality to jurisdictional determinations-aside from "constitutional" jurisdictional facts in cases involving "private rights"- has become so general as now to constitute a well-established and consistent practice also when there is no express language in the respective statute dealing with jurisdictional questions. The existence of such practice is shown not only by the opinions, listed in the footnote, citing the Shields opinion, but also by some additional recent cases in which no reference was made to the Shields decision, namely, South Chicago Coal \& Dock Co. v. Bassett, ${ }^{\text {ror }}$ Rochester Telephone Corp. v. United States, ${ }^{102}$ Endicott Johnson Corp. v. Perkins, ${ }^{103}$ and National Labor Relations Board v. Hearst Publications. ${ }^{\text {I04 }}$

In the Bassett case, which involved the Longshoremen's and Harbor Workers' Compensation Act, the authority to determine whether an individual when he sustained his injuries was "a member of a crew" held to be confided to the authority of the deputy commissioner, the Chief Justice relying on statutory provisions ${ }^{\text {rot }}$ which are no more specific with respect to matters of jurisdiction than is the language of the Railroad Retirement Act. The Bassett case deserves special interest for two reasons:

${ }^{100}$ The Shields case was so cited in the following opinions: Ziffin, Inc. v. United States, 3 I8 U.S. 73, at 80 (I943); O'Malley v. United States, 38 F. Supp. I, at 4 (I94I); and Johnson v. United States, 4I F. Supp. I88 (I94I). All three cases involved determinations of the Interstate Commerce Commission under the so-called "grandfather-clause" of the Motor Carrier Act. The statutory provisions involved are sections 209 (a) and (b), and section 2 ro of the Interstate Commerce Act. According to the proviso of section 209 (a) a permit for the performance of service as a contract carrier by motor vehicle shall be issued by the commission without further proceedings "if any such carrier or a predecessor in interest was in bona fide operation as a contract carrier by motor vehicle on July $x$, I935." No provision of the Interstate Commerce Act confers express authority upon the commission to determine this jurisdictional question.

The Shields case was also so cited in Gray v. Powell, 3I4 U.S. 402, at 4II (I94I), which concerned a determination of "producer" under the Bituminous Coal Act of 1937, 50 Stat. 72, ch. I 27, I5 U.S.C. $\$ 828$. This statute ceased to be effective on April 26, I943. While the act contained express provisions on the limited scope of judicial review and on the requirement of hearings, there was no express provision in the act intrusting the Bituminous Coal Commission with authority to make "producer" determinations. Section $4-\mathrm{A}$ of the act, to be sure, specifically conferred power upon the commission to rule upon applications by producers for exemption from the act, but that provision failed to specify expressly the power to make "producer" determinations as such, at least in the express manner apparently demanded under the test set up by the Circuit Court of Appeals for the Tenth Circuit in the Utah Copper opinion.

$$
\begin{array}{ll}
{ }^{101} 309 \text { U.S. } 25 \text { (1940). } & { }^{103} 3 \text { I } 7 \text { U.S. 50r (I943). } \\
{ }^{102} 307 \text { U.S I25 (1939). } & { }^{204} 3^{22} \text { U.S. III (I944). }
\end{array}
$$

${ }_{105}$ Section 3 of the act-33 U.S.C. $\$ 903$-(the section entitled "Coverage") specifically excludes members of a crew from compensation benefits.

${ }^{106} 33_{2}^{5}$ U.S.C. 919 (a), 921. 
First, it was concerned with the same statute under which Crowell v. Benson arose, thus suggesting that when the Court fails to find a constitutional issue, jurisdictional determinations are treated in the same manner as other determinations. ${ }^{\text {I07 }}$ Second, it was written by Mr. Chief Justice Hughes who had been the author of the Shields opinion, as also of the majority opinion in Crowell v. Benson, a clear indication that in the Shields opinion the Chief Justice did not purport to establish any rule such as the circuit court in the Utah Copper case professed to find therein.

The Rochester Telephone case, a landmark of administrative law because of its demolition of the so-called "negative order" doctrine, has some bearing on the subject here in question. Under an exemption provision of the Federal Communications Act of $1934^{\mathrm{ro8}}$ the Federal Communications Commission shall not have jurisdiction with respect to "any carrier engaged in interstate or foreign communication solely through physical connection with the facilities of another carrier not directly or indirectly controlling or controlled by, or under direct or indirect control with, such carrier." Without citing any specific statutory provisions in support, $\mathrm{Mr}$. Justice Frankfurter held that determinations of the jurisdictional question of "control" under that provision were committed to the commission. ${ }^{109}$ Although the Communications Act contains detailed provisions concerning the powers of the commission and the requirement of hearings, ${ }^{\text {IIO }}$ no express language is contained in that act conferring authority upon the commission concerning determination of the jurisdictional issue which was involved in the Rochester case.

The same is true with respect to Endicott Johnson v. Perkins, involving a subpoena issued by the Secretary of Labor pursuant to the WalshHealey Act. ${ }^{\mathrm{Ix}}$ It was held in that case that the principle of administrative finality includes the Secretary's determination of coverage under that act. Again, the statute contains no express language specifically intrusting the Secretary with authority to determine the jurisdictional question of coverage. ${ }^{\mathrm{Ixz}}$ And it should be noted that in the recent case of National Labor

${ }_{\text {I07 }}$ See also Hagens v. United Fruit Co., I35 F. 2d 842 (I943); Schantz v. American Dredging Co., I38 F. 2d 534 (I943).

${ }^{108} \S 2$ (b) (2); 48 Stat. 1065 (1934), 47 U.S.C. $\$ 152$ (b) (2).

${ }^{109} 307$ U.S. 125 , at $x_{45}$ (1939).

${ }^{110}$ See e.g. 47 U.S.C. $\$ \S I_{54}$ (i), 2I3 (a), 2I3 (f), 214 (d), 2I5, 221 (a); see also $\S 22 I$ (c) concerning classification of property of carriers engaged in wire telephone communication.

${ }^{r x} 49$ Stat. 2036 (1936) 4 I U.S.C. $\$ 35$.

${ }^{112}$ The only provisions concerning the authority of the Secretary under the act are sections 4 and 5 ( 4 I U.S.C. $\$ \$ 38$ and 39 ), neither of which, however, is specifically concerned with the question of coverage. Another recent Supreme Court decision in which despite the absence of 
Relations Board v. Hearst Publications, ${ }^{\mathrm{x} 3}$ which involved an "employee" determination by the National Labor Relations Board-a determination similar to the "employee" determinations under the Railroad Retirement Act - the Supreme Court, citing among others its opinions in Gray v. Powell, South Chicago Coal \& Dock Co. v. Bassett, and Rochester Telephone Corp. v. United States, held that "the question who is an employec under the Act... . 'belongs to the usual administrative routine' of the Board," and that "the Board's determination that specified persons are "employees' under this Act is to be accepted if it has 'warrant in the record' and a reasonable basis in law." The Supreme Court did not even mention the concept of "jurisdictional facts."

Clearly, there is no such special rule in the field of judicial review with respect to "jurisdictional questions," as was contended for by the Circuit Court of Appeals for the Tenth Circuit in Utah Copper Co. v. Railroad Retirement Board. In fact, in a more recent opinion which involved an "employer" determination by the Railroad Retirement Board (Duquesne Warehouse Co. v. Railroad Retirement Board $\left.{ }^{154}\right)$, the District Court for the Southern District of New York, though referring to the decision in the Utah Copper Co. case (and citing Crowell v. Benson), held specifically that:

If the findings of fact which form the basis for the determination that Duquesne is an "employer" within Section I (a) of the Retirement Act are supported by substantial evidence, it is clear from reading the Act and the Regulations promulgated under the Act that the Board has jurisdiction.

"Employer" and "employee" determinations under the Railroad Retirement Act, it appears, do not differ with respect to the board's authority from any other determination to be made in the administration of the Railroad Retirement Act. For the eligibility for, and the amount of, awards under the Railroad Retirement Act are necessarily dependent upon "employer" as well as "employee" determinations. ${ }^{\text {Irs }}$ Such determina-

express statutory language an incidental question of jurisdiction, at least implicitly, was held covered by the principle of administrative finality, is the case of Swift \& Co. v. United States, 3 I6 U.S. 216 , at 230,23 I (1942) (determination as to what constitutes "transportation" within the meaning of the Interstate Commerce Act; the only statutory language of the act dealing with the authority exercised by the commission in that case $\left(\$ I_{5}(\mathrm{I})\right.$ ), is directed to authorizing determinations with respect to the reasonableness of a carrier practice).

${ }^{{ }^{2} 3} 322$ U.S. III, r30, r3I (1944).

${ }^{x_{4}} 5_{5}$ F. Supp. 87,89 (I944).

"Section 2 (a) of the Railroad Retirement Act of 1937 (the provision determining "eligibility" for "annuities") requires that the individuals shall have been "employees"; and, as mentioned, the term "employee" is in turn defined (in section I (b)) by reference to the term "emplojer" (defined in section I(a)). The "pensions" pajable under section 6 of the act are to be paid to certain individuals who were on the pension or gratuity roll of an "employer." 
tions are therefore necessary in order to enable the board to carry out the mandate of Congress to administer the railroad retirement legislation, and the statutory provisions referred to $0^{126}$ as the basis for applying the doctrine of administrative finality to the board's determinations generally, are all-comprehensive and do not permit any exclusion of "jurisdictional questions."

\section{EVIDENCE BEFORE ADMIINISTRATIVE AGENCIES}

As mentioned, problems concerning evidence have arisen in litigation under the Railroad Retirement Act. The problem as to whether, and to what extent, rules of evidence must be observed by an administrative agency, promises to become one of the most significant questions in the field of administrative law. With the constant expansion of the field of administration and with its assumption of an increasing number of varied types of functions, the question of evidence is bound to arise under many different circumstances. Peculiar to Anglo-American law due to the absence in so-called civil law countries of any comparable system of rules of evidence, the problem of evidence in most instances must be considered by the courts without the support of direct statutory language. Different from the question as to the scope of the judicial review of administrative actions, express language on the question of evidence is found only in a very limited number of federal statutes. ${ }^{117}$ For example, a specific provision that the "rules of evidence prevailing in courts of law or equity shall not be controlling" was included in the Railroad Unemployment Insurance Act

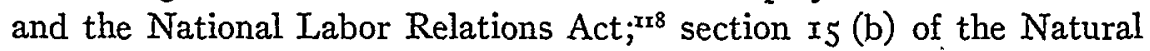
Gas Act ${ }^{\mathrm{rr} 9}$ specifies that in the conduct of all hearings, investigations, and proceedings under the act the "technical rules of evidence need not be applied"; and the Social Security Act, as amended, ${ }^{\mathrm{xa}}$ is especially explicit on the subject in question by providing not only (in section 205 (b)) that "evidence may be received at any hearing before the Board even though inadmissible under rules of evidence applicable to court procedure," but by further specifying (in section 205 (c)) that the records maintained

${ }^{216}$ Supra, pp. 39-4I.

${ }^{x \rightarrow}$ Express provisions freeing the commissions from the rules of evidence are contained in many of the state workmen's compensation statutes.

${ }_{118} \S 5$ (e) of the Railroad Unemployment Insurance Act ( 52 Stat. Iroo (r938) 45 U.S.C. $\S 355$ (e)); $\S$ 10 (b) of the National Labor Relations Act ( 49 Stat. 453 (1935) 29 U.S.C. $\S$ 160 (b)). The provision of the National Labor Relations Act was considered and interpreted in numerous court decisions.

${ }^{129} 5^{2}$ Stat. $830(1938) x_{5}$ U.S.C. $\$ 717 n$.

${ }^{230} 53$ Stat. ${ }_{3369}$ ( $\left.\mathrm{x} 939\right)_{42}$ U.S.C. $\$ \S 405$ (b) and (c). 
by the Social Security Board of the amounts of the wages paid to each individual and of the periods in which such wages were paid, "shall be evidence, for the purpose of proceedings before the Board or any court, of the amounts of such wages and the periods in which they were paid, and the absence of an entry as to an individual's wages in such records for any period shall be evidence that no wages were paid such individual in such period."

Since such express language is very rare in federal statutes, the courts frequently have based their conclusion of the inapplicability of the strict common law rules of evidence upon statutory provisions of a more general character. Provisions establishing the substantial evidence rule or declaring that the jurisdiction of the administering officials shall include the power to make the rules of their own procedure have been construed to contain an implied sanction of the independence of such officials from the jury-trial rules of evidence. ${ }^{\text {ra }}$ For example, the rule of the Federal Trade Commission Act limiting the scope of judicial review ${ }^{122}$ has been construed to permit admission of legally incompetent testimony. ${ }^{\text {x23 }}$

A general statement concerning the inapplicability of the technical exclusionary rules of evidence to proceedings before federal administrative agencies was made by Mr. Justice (now Chief Justice) Stone in the wellknown Opp Cotton Mills case, ${ }^{\mathrm{I24}}$ which case, together with United States v. Darby, ${ }^{\text {x25 }}$ decided the same day (February 3, I94I), upheld the constitutionality of the Fair Labor Standards Act of I938. The Opp Cotton Mills case, a landmark in the field of public law because of its extensive discussion and modern interpretation of the problem of delegation of legislative powers, ${ }^{\mathrm{I} 26}$ contains some discussion of the problem here under consideration. In connection with the question as to whether a finding of the Administrator of the Wage and Hour Division of the Department of Labor

\footnotetext{
${ }^{\text {r2x }}$ See I Wigmore, Evidence p. 44 (3d ed. x940); for a discussion of the similar rule of New York law, see Benjamin, Administrative Adjudication in the State of New York p. I7 If. (I942).

${ }^{22}$ Supra, note 28.

${ }^{233}$ Hills Bros. v. Federal Trade Commission, 9 F. 2d 48r, 484 (I926); Arkansas Wholesale Grocers' Ass'n v. Federal Trade Commission, i 8 F. 2d 866 (I927); John Bene \& Sons v. Federal Trade Commission, 299 Fed. 468, at 47 I (I924): “. . . . evidence or testimony, even though legally incompetent, if of the kind that usually affects fair-minded men in the conduct of their daily and more important affairs, should be received and considered."

${ }^{124} 312$ U.S. 126 (I94I).

1253 I2 U.S. $x 00$ (I94I).

${ }_{126}$ For a discussion of the comparative-law aspects of that problem, see the writer's article. Delegation of Powers and Judicial Review, 36 Col. L. Rev. 87I (I936), 4 Selected Essays on Constitutional Law 316 (I938).
} 
was supported by substantial evidence (the Fair Labor Standards Act contains a provision that "findings of fact by the Administrator when supported by substantial evidence shall be conclusive"), objection had been made by the petitioners to the class of evidence included in the record, such as statistical publications by the Bureau of Labor Statistics, the Interstate Commerce Commission, the Federal Trade Commission, and the Wage and Hour Division. Rejecting the petitioners' argument, Mr. Justice Stone stated $:^{: 27}$

The argument of petitioners is not that the record contains no evidence supporting the findings but rather that this class of evidence must be ignored because not competent in a court of law. But it has long been settled that the technical rules for the exclusion of evidence applicable in jury trials do not apply to proceedings before federal administrative agencies in the absence of a statutory requirement that such rules are to be observed [citing cases.] ${ }^{\mathrm{r} 28}$

That the common law rules of evidence, on general principles, should not be applied to inquiries of fact determinable by administrative tribunals has often been the subject of discussion by legal writers. As stated by Wigmore, ${ }^{\text {,29 }}$ there is no historical justification for applying the rules of evidence, for they grew up exclusively in jury trial and therefore do not apply "ex stricto jure" in any tribunal but a jury court. Numerous arguments of policy, also, are advanced against application of the rules of evidence, especially in the case of non-adversary administrative proceedings; the requirements of the rules of evidence are declared to be inconsistent with the prime objectives of administration, viz., the objectives of despatch, elasticity, and simplicity; ${ }^{\mathbf{3} 30}$ because of the fact that administrative tribunals are composed of experienced professional men, habitually inquiring day after day into the same limited class of facts, an expert

I27 At p. 155 .

${ }^{128}$ See also United States ex rel. Tisi v. Tod, 264 U.S. I3I, I33 (I924), a deportation case, in which Mr. Justice Brandeis stated that in deciding whether a warrant of deportation should stand, the test is not "whether the evidence was such that, if introduced in a court of law, it would be held legally sufficient to prove the fact found."

${ }_{229}$ Evidence (3d ed. I940) vol. I, p. 27.

${ }^{130}$ Final Report of the Attorney General's Committee on Administrative Procedure 7o (I94I) see also Stephens, Administrative Tribunals and the Rules of Evidence (I933); Davis, An Approach to Problems of Evidence in the Administrative Process, 55 Harv. L. Rev. 364 (I942), and 2 Vom Baur, Federal Administrative Law $\$ 579$ (I942); but see also Riedl, Should Rules of Evidence Govern Fact-Finding Boards? 23 Marq. L. Rev. I3 (I938). An interesting discussion of the problem here in question, with an examination of the applicability of certain specific rules of evidence, is furnished by Stephan, The Extent to Which Fact-Finding Boards Should be Bound by Rules of Evidence, 24 A.B.A.J. 630 (1938); see also Miller, Application of Rules of Evidence to Fact-Finding Boards, I 7 Chicago-Kent L. Rev. I45 (I939). For a recent discussion see Merrill, Judicial Review of Administrative Proceedings, a Functional Prospectus, 23 Nebr. L. Rev. 56, 64-68 (I944). 
weighing of evidence can generally be counted upon, and therefore there is no justification for applying the rules of evidence, most of which are merely rules of caution designed to exclude possible sources of error; the courtroom rules of evidence are declared to be manifestly inappropriate for many of the administrative procedures which require investigative techniques; furthermore, it is suggested that imposition of the jury-trial system of evidence upon administrative tribunals could not be accomplished without imposing the lawyers also upon them, a result which is believed by many to be very undesirable and inconsistent with the purposes and functions of administration. ${ }^{\mathrm{xx}}$

Like most federal statutes, the Railroad Retirement Act does not contain any express language on the problem here under consideration..$^{132}$ Of course, the necessity of accepting and relying upon various types of informal evidence is particularly apparent in the case of the "disbursing" agencies of the federal government which constantly handle large numbers of small claims. Thus, the practice of the Railroad Retirement Board, as one of the federal "disbursing" agencies, ${ }^{{ }^{133}}$ to accept informal evidence has been noted with approval by official reports and by legal scholars. ${ }^{\text {I34 }}$ In this respect the "Administrative Procedure Bill," American Bar Association, appears to be deficient. Section 6 (c) of the bill provides, concerning the "hearings" before the administrative agency contemplated by the bill, that: "The principles of materiality, probative force, and substantiality as recognized in judicial proceedings of an equitable nature shall govern the proof, decision, and administrative or judicial review of all questions of fact." While there seems to be a tendency to relax the common law rules of evidence in procedures of an equitable nature, clearly no definite system has as yet emerged of rules of evidence as applicable to equitable actions. True, certain qualifications of the common law rules of evidence have been noted in equity cases, ${ }^{136}$ and on the basis of

${ }^{{ }^{32}}$ See Wigmore, op. cit. p. 36 .

${ }^{232}$ The proposed "Railroad Social Insurance Act" (see supra, note 29) contains a specific provision ( $\$ 406(\mathrm{e}))$ that "Common law and statutory rules of evidence, including but not limited to rules excluding declarations of deceased persons and privileged communications, shall not be controlling."

'.33 Other "disbursing" agencies of the federal government are the Veterans' Administration, the Social Security Board, and the Employees' Compensation Commission.

${ }^{234}$ See Final Report of the Attorney General's Committee on Administrative Procedure pp. 35-42, 70, 7x, 398, 399 (I94I); Davis, op. cit., supra, passim; Gellhorn, Federal Administrative Proceedings 79 (I94I).

ז35 Supra, note II.

${ }^{23^{6}}$ See, e.g., Wigmore, op. cit., supra, vol. x, pp. 14 ff. 
a "summary of evidence principles for a non-jury tribunal" as formulated by Wigmore, application of such qualified system to administrative agencies has been advocated. ${ }^{\mathrm{x} 7}$ However, the contents of any such system, if at all perceptible in the present state of legal development, seem to be extremely vague, so that enactment of the "Administrative Procedure Bill" apparently would fail to establish any unequivocal rule concerning evidence before administrative agencies. And while it is true that section 6 (c) of the bill specifically authorizes all agencies to "adopt procedures for the disposition of contested matters in whole or in part upon the submission of sworn statements or written evidence subject to opportunity for .... cross-examination or rebuttal," it would not appear desirable to apply any court rules on "materiality, probative force, and substantiality" (and therefore, possibly, of at least certain aspects of the hearsay rule ${ }^{\mathrm{x}_{3} 8}$ ) to the activities of the federal disbursing agencies. In fact, a modification of the provisions of section 5 (e) of the Railroad Unemployment Insurance Act and of section 205 (b) of the Social Security Act would result from an enactment of the proposed bill.

In the absence of specific language in the statute the courts have sanctioned the acceptance by the Railroad Retirement Board of informal evidence, without requiring observance of any court rules of evidence. While the problem was passed upon sub silentio in numerous of the abovementioned court decisions, in which board orders were upheld under the substantial evidence rule-for those orders had been based upon informal evidence-express discussions of the problem are contained in two court decisions, Ellers v. Railroad Retirement Board ${ }^{\mathrm{x} 39}$ and Taylor v. Latimer, Railroad Retirement Board..$^{\text {I }}$ In the latter case the plaintiff had complained that the "evidence before the board did not come up to the usual standards of a proper procedural inquiry," because in determining whether the plaintiff was "totally and permanently disabled for regular employment for hire" within the meaning of the Railroad Retirement Act, the board had relied upon reports of a medical examination by the Veterans Facility at Excelsior Springs, Missouri. The court rejected that contention, stating that "it needs no citation of authorities to suggest that the

${ }^{137}$ Vanderbilt, The Technique of Proof before Administrative Bodies, 24 Ia. L. Rev. $4^{64}$ (1939).

${ }^{{ }^{38}}$ For a specific suggestion that administrative agencies disregard all exclusionary rules of evidence, see, e.g., Swancara, Exclusionary Rules of Evidence in Administrative Hearings (1939) II Rocky Mt. L. Rev. 77 (1939).

${ }^{139}$ I32 F. 2d 636 (I943).

${ }^{x_{40}^{\circ}} 47$ F. Supp. 236 (r942). 
law contemplates informality in the proceedings before administrative boards. The courts hold such boards only to the duty of receiving dependable and reliable evidence; that means, such as reasonable persons would rely upon as expressive of the truth." ${ }^{4}$

The decision in the Ellers case is of general significance in the field of administrative law because of the reason which the court advanced for its conclusion that the board is not restricted by the rules of evidence applicable in court proceedings. Reversing the lower court ${ }^{\mathrm{T} 4 z}$ which had held that the evidence relied upon by the board in support of its decision was insubstantial because it consisted of reports, answers to questionnaires, and letters, none of which was under oath, whereas Ellers' evidence consisted of affidavits, the Circuit Court of Appeals for the Second Circuit held that the district court was in error in drawing a distinction between sworn and unsworn evidence and in ascribing controlling weight to the former. Judge Swan, delivering the opinion of the circuit court, stated:

Administrative agencies are usually not restricted to the same rules of evidence as apply in court proceedings, even in the absence of an express statutory provision on the subject. [citing authorities.] While the Board is given power to compel the attendance of witnesses, administer oaths and take testimony, 45 U.S.C.A. $\$ 228$ j (b) 4 , its administration of the Acts is not confined to information obtained by testimony. The same section authorizes it to "make all necessary investigations in any matter involving annuities or other payments"; and to "require all employers and employees .... to furnish such information and records as shall be necessary for the administration" of the Acts. If an employer wilfully refuses to make a report or knowingly reports false information he is subjected to severe criminal penalties by $\S \mathrm{I} 3$ of the Act, 45 U.S.C.A. $\$ 228 \mathrm{~m}$. It is clear, therefore, that in adjudicating claims for annuities the Board is permitted to consider evidence which would be objectionable in a court of law, and if it is of a kind on which fair-minded men are accustomed to rely in serious matters, it can support an administrative finding. See National Labor Relations Board v. Remington Rand, 2 Cir., 94 F. 2d. 862, 873. The evidence received was of this character. The weight to be accorded it was for the Board to determine. . . . ${ }^{143}$

By thus sanctioning not only the receipt of written statements generally, without regard to whether they would, as such, be admissible in a court under one of the exceptions to the hearsay rule, if properly introduced in accordance with the law of evidence, but also by sanctioning specifically the receipt of such written statements whether or not sworn to, the court effectively freed the board of shackles, destructive of the purposes of the legislation, which would have been created if it had been required that the technical rules of evidence be observed by the board. It is interesting that

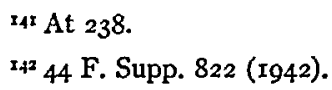

${ }^{43}$ I $_{32}$ F. $2 \mathrm{~d}$ at 639. 
the court apparently was not satisfied with enunciating general principles, as is frequently done by courts in similar opinions, but that it based its conclusion on specific statutory language. Permission to consider evidence which would be objectionable in a court of law was seen by the court in the statutory provision (section Io (b) 4 of the act) by which the board is given power to "make all necessary investigations in any matter involving annuities or other payments" and to "require all employers and employees.... to furnish such information and records as shall be necessary for the administration" of the acts. And the criminal sanctions provided in section I $_{3}$ of the act for wilful refusals to make reports or knowingly reporting false information were considered by the court to be a clear indication that the receipt of unsworn evidence was contemplated by the act. This manner of reasoning by the court is novel to some extent in that, in an eminently proper way, it relates the problem of evidence before the administrative agency to the latter's general investigatory powers, such approach demonstrating a clear perception of the nature of the administrative process. The decision in the Ellers case thus acquires distinction as an important pronouncement in the general development of administrative law, beyond its immediate function of construing a specific statutory enactment.

\section{CONCLUSION}

Certain conclusions are suggested by the above discussion. While, as stated, the controlling importance of the specific statutory material has been characteristic of the development of American administrative law, certain general principles nevertheless seem to be in the process of crystallization. Our discussion of court decisions under the Railroad Retirement Act concerning the issues of judicial review and of evidence has shown that even in the absence of specific language in the statute certain elementary rules are likely to be adopted by the courts. Both principles here involved, the principle limiting the scope of judicial review and the principle as to the inapplicability of the rules of evidence, are basic rules which deeply affect the very foundation of administrative law itself. As generally recognized, it is the function of administrative law to determine the proper coordination between administrative matters and traditional principles of law, by regulating the scope and the appropriate limits of administration and by prescribing the proper relationship between rules of law and the modern scheme of administration. The extent to which courts may exercise reviewing functions over the administration, and also the question concerning the relationship between the common law rules of evidence 
and the procedure before administrative agencies, thus are matters which go to the very heart of administrative law. The treatment given to those matters by the courts in the interpretation of the Railroad Retirement Act, without the assistance of express statutory language, demonstrates that the present-day approach of the courts to some of the basic issues of administrative law constitutes an expression of policy which is sound in that it grants proper status to the administrative determinations and in that it does not cripple the exercise of administrative functions by an attempt to force those functions into traditional common law concepts. If consistently developed in accord with such an approach, administrative law promises to become a means of effectuating, rather than a hindrance to, efficient administration. 